\title{
НЕБЕЗПЕКА ТА РИЗИКИ ЗАСТОСУВАННЯ НАНОТЕХНОЛОГІЙ В ТЕКСТИЛЬНІЙ ПРОМИСЛОВОСТІ
}

Е.В. ПАХОЛЮК

Луиякий национальный технический университет

\section{ОПАСНОСТЬ И РИСКИ ПРИМЕНЕНИЯ НАНОТЕХНОЛОГИЙ В ТЕКСТИЛЬНОЙ ПРОМЫШЛЕННОСТИ}

\author{
O. PAKHOLIUK \\ Lutsk National Technical University
}

\section{DANGER AND RISK OF NANOTECHNOLOGY APPLICATION IN TEXTILE INDUSTRY}

\section{https://doi.org/10.36910/6775-2310-5283-2018-11-12}

Мета. Узагальнення результатів європейських і українських наукових досліджень ринку текстильних матеріалів з використанням нанотехнологій щэодо підтвердженої їх безпеки і можливої токсичності та визначення потенційних ризиків.

Методика. При проведенні досліджень використовували передбачені діючими державними стандартами методи. Виконали огляд джерел товарознавчої та медичної інформації, здійснили моніторинг і систематизацію отриманих даних.

Результати. Можна стверджувати, що у ході наукових досліджень ризиків $i$ небезпеки наноматеріалів в текстильній промисловості, необхідно використовувати надійні методи. Будь-які недоліки в науковій оиіниі ризику викликатимуть негативне ставлення суспільства до нанотехнологій, що може призвести до сповільнення розвитку нових перспективних технологій.

Проте комериійний розвиток нанотеїнологій та їх численні застосування можуть спричинити широкий спектр загроз здоров'ю людини. Наноматеріали, які вже використовуються в текстильній промисловості, потрапили на ринок в умовах недостатнього екогігієнічного нагляду, який має бути побудований з урахуванням їх нетрадиџійних властивостей. Враховуючи обмеженість даних щодо впливу наночастинок на організм, необхідно проводити обов'язкові фармакокінетичні та токсикологічні дослідження перед широкомасштабним їх виробництвом та використанням.

Наукова новизна. Узагальнено результати європейських $і$ украӥнських наукових досліджень ринку текстильних матеріалів з використанням нанотехнологій щзодо підтвердженої їх безпеки і можливої токсичності та визначення потенційних ризиків.

Практична значимість. Представлені результати дослідження надають підстави вважати, щзо наночастинки з розмірами та площею поверхні близькими до частинок надмалого розміру ймовірно будуть викликати тяжкі захворювання, а деякі ще й з довгим латентним періодом. Враховуючи широке індустріальне розповсюдження нанотехнологій, є потенщійна загроза забруднення повітря та виникнення значної загрози для населення.

Ключові слова: нанотекстиль, нанотехнології, нановолокна, ризики застосування нанотехнологій, безпека використання, потенційні наслідки.

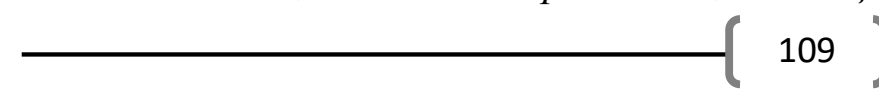


Постановка проблеми у загальному вигляді та іï зв'язок із важливими науковими чи практичними завданнями. Останнє десятиріччя характеризується підвивщенням інтересу суспільства до нанотехнологій, які сприяють підвищенню якості і продуктивності матеріалів i технологій, надаючи їм нові властивості чи покращуючи існуючі параметри. У майбутньому продукти нанотехнологій, імовірно, вплинуть на всі галузі промисловості і вийдуть на ринки у великих обсягах. Усвідомлюючи неминучість цього і розуміючи величезні перспективи нанотехнологій, країни світу інвестують великі кошти у розвиток цієї галузі [8].

Цілком природно, що світові тенденції не оминули потужний ринок текстилю, котрий тісно пов'язаний зі світом моди і знаходиться в постійній залежності від модних тенденцій і сезонних коливань. Сфера застосування сучасних видів наноматеріалів і нановолокон досить широка та різноманітна. Нановолокона ввикористовуються для створення багатофункціональних матеріалів i виробів спеціального призначення ("розумний" текстиль, куленепробивний одяг для силових структур, високогігроскопічні матеріали для спортивного одягу та інші). Також широко використовуються як армуючі елементи в багатьох видах композиційних матеріалів, що нині успішно використовуються в різних галузях промисловості (автомобільній, авіаційній, ракетобудівній, суднобудівній та багатьох інших). Крім цього, ці волокна знайшли різноманітне застосування в медицині для виготовлення текстильних матеріалів i виробів медичного призначення (одяг для медперсоналу та хворих, лікувальні антимікробні покривні матеріали та інші) [1,2].

У текстильній промисловості розвинених країн широко впроваджується виробництво нановолокон і завершальне оброблення тканин на нанорівні. Волокна, наповнені наночастинками, мають знижену усадковість, горючість, підвищену міцність, витривалість та зносостійкість. Хімічні волокна набувають високих електро- i теплопровідних властивостей, хімічної активності, стійкості до УФ-випромінювання, підвищеної міцності і витривалості під час згинання. Всі види текстильних матеріалів, а особливо одяг і взуття, які виготовляються 3 використанням нанотехнологій і містять наночастки, представляють певну небезпеку як для навколишнього середовища, так і для здоровя людини, як і всі нанопродукти. Отже, виникає питання про токсичність застосування наноматеріалів і нанотехнологій в текстильній промисловості для здоров’я людини. 
Аналіз останніх досліджень, у яких започатковано вирішення проблеми. Протягом кількох років багато організацій в усьому світі здійснюють дослідження 3 оцінки ризику використання наноматеріалів. Думки токсикологів щодо підходу до оцінки безпеки наноматеріалів дуже різняться: одні вчені вважають, що наноматеріали $є$ новими речовинами, а тому необхідне додаткове ретельне вивчення їхньої безпеки. Таке дослідження не має обмежуватись питанням про токсичність самої сполуки, варто враховувати форму частинок і ступінь мініатюризації (розміри частинок та їх розподіл за розміром), співвідношення площі поверхні до маси тощо. Інші токсикологи вважають, що наноматеріали можуть виявляти підвищену системну токсичність і цитотоксичність, а також змінену токсикокінетику $[4,5]$.

Аналіз літературних джерел, присвячених застосуванню нанотехнологій для формування асортименту, властивостей i якості текстилю, дозволяє зробити наступні узагальнюючі висновки [1]:

- інформація про можливість використання нанотехнологій для формування асортименту та властивостей текстилю, яка міститься в періодичних, монографічних і навчальних вітчизняних і зарубіжних виданнях, носить епізодичний характер і потребує систематичного поповнення та детального аналізу;

- відсутні обгрунтовані дані про економічну, екологічну та технологічну доцільність використання сучасних нанотехнологій у вітчизняному текстильному виробництві 3 врахуванням потреб сучасного ринку екотекстилю;

- відсутня об’єктивна і доступна інформація про вплив сучасних нанотехнологій виробництва текстильних матеріалів і виробів на екологічну безпечність цих товарів, а також здоров'я людини та забруднення довкілля;

- не сформульовані обгрунтовані та стандартизовані вимоги до асортименту, властивостей та рівня якості та конкурентоспроможності текстилю різного цільового призначення, отриманого на основі застосування нанотехнологій;

- не внесені необхідні доповнення, зміни та уточнення в існуючу систему вітчизняної екологічної стандартизації, які стосуються термінів і визначень, нормативів екологічної безпечності, вибору критеріїв і методів іiі оцінювання та контролю якості текстильної сировини та готової продукції, отриманої на основі використання сучасних нанотехнологій; 
- відсутня класифікація і загальна характеристика нанотехнологій, які вже знайшли практичне застосування в окремих підгалузях вітчизняного текстильного виробництва;

- відсутня характеристика стабільності та довговічності ефектів, які досягаються на текстильних матеріалах в результаті використання для їх виробництва нанотехнологій;

- ще недостатньо вивчено та обгрунтовано механізм взаємодії різних видів наночастинок 3 текстильними волокнами та виявлені найбільш перспективні варіанти їх використання.

Метою статті $\epsilon$ узагальнення результатів європейських і українських наукових досліджень ринку текстильних матеріалів 3 використанням нанотехнологій щодо підтвердженої їх безпеки i можливої токсичності та визначення потенційних ризиків.

Виклад основного матеріалу дослідження 3 повним обгрунтуванням отриманих наукових результатів. Безпека використання будь-якої речовини у складі текстильних матеріалів визначається ймовірністю іiі системного впливу на організм після контакту зі шкірою. Так, одяг, нижня і постільна білизна, головні убори, взуття безпосередньо чи опосередковано контактують зі шкірою людини, домашній текстиль формує середовище існування людини, гігієнічний текстиль особливо тісно зв'язаний з людиною.

Всі текстильні вироби з точки зору безпеки для здоровя людини (згідно ЕКОТЕКС), поділяються на наступні групи [3]:

- вироби для дітей - текстиль та аксесуари для немовлят і дітей до 2-ох років (найжорсткіші вимоги щодо безпеки);

- текстильні вироби, значна частина поверхні яких, контактує зі шкірою людини (жорсткі вимоги);

- текстильні матеріали, які не мають прямого контакту зі шкірою людини, мала частина поверхні яких контактує зі шкірою;

- декоративні текстильні вироби, які не контактують зі шкірою людини, (потрапляння шкідливих речовин здійснюється через дихальні шляхи).

Незначні та несистемні дослідження по впливу наносполук на людей i тварин, все ж таки дозволяють зробити наступні висновки [3]:

- разове потрапляння наноматеріалів в організм людини викликає небажані зміни, інтенсивність яких залежить від концентрації наноматеріалів;

- наноматеріали мають властивість накопичуватись в органах та тканинах (кістковий мозок, нервові клітини центральної та переферичної нервових систем, легенях, печінці, нирках). 
Для системного впливу речовина має подолати епідермальний бар'єр i досягти глибших шарів шкіри і потрапити у кров. Однак навіть під час потрапляння до системи кровообігу речовини швидко захоплюються імунними фагоцитами - макрофагами і моноцитами. Тому малоймовірно, що наночастки, котрі проникли крізь шкіру, знаходитимуться у кровотоці в незмінному вигляді. Непрямим доказом цього є результати, отримані під час внутрішньовенного застосування наночастинок у лікарських засобах: наночастинки умить були захоплені фагоцитами[4,5].

Певна частина вчених вважають, що достатньо звичайного підходу до оцінки ризиків, пов'язаних із наноматеріалами, і всі можливі особливості їхніх токсичних властивостей можна оцінити за допомогою типових токсикологічних параметрів. Однак загалом результати дискусії щодо наноматеріалів засвідчують, що вони можуть завдати людині нову небезпеку, і звичайної методології оцінки їхньої безпеки недостатньо. Нажаль, подібні твердження нечасто супроводжуються документально підтвердженими результатами досліджень. У багатьох працях ризик, пов'язаний із наноматеріалами, розглядається як потенційний, а отже, залишається гіпотетичним. Під час обговорення токсичності наноматеріалів токсикологи дійшли до висновку, що основну небезпеку ці матеріали становлять під час вдихання. Також, останні дані свідчать, що вдихання наночастинок не призводить до значного системного впливу завдяки ефективному фагоцитарному бар'єру [4,5].

Як і будь-який інший новий матеріал або технологія, наночастинки потенційно можуть виявляти й небезпеку для довкілля.

Значна кількість досліджень вказують на взаємозв'язок між впливом частинок надмалого розміру та рівнем захворюваності у людей похилого віку та осіб з підвищеною чутливістю. $€$ всі підстави вважати, що наночастинки 3 розмірами та площею поверхні близькими до частинок надмалого розміру ймовірно будуть викликати подібні захворювання, а деякі ще й 3 довгим латентним періодом. Враховуючи широке індустріальне розповсюдження нанотехнологій, $є$ потенційна загроза забруднення повітря та виникнення значної загрози для населення.

Залишається невирішеним одне з головних питань, а саме обмеженість інформації про можливі загрози здоров'ю від впливу різних наноматеріалів. Необхідним $\epsilon$ прийняття спеціальних законів для нанотехнологій промисловості, що будуть враховувати особливості виробництва, наголошувати на здійсненні обов'язкового моніторингу впливу на робітників 
та контролю випуску наночаснинок, проведенні оцінки ризиків при їх застосуванні $[4,5]$.

Свропейська система оцінювання якості ЕКОТЕКС (100 і 200) містить основні вимоги до показників безпеки текстильних матеріалів і методи їх дослідження. Вона визначає норми вмісту хімічних речовин в текстильних матеріалах. Проте, ЕКОТЕКС була сформована ще до ери нанотехнологій i потребує певних доповнень i корекції, як 3 точки зору асортименту використовуваних наночастинок, так i методів їх виявлення i нормування вмісту.

Проте, нанотекстиль може не тільки нести небезпеку для здоров’я людини, але i захищати іï (захисний нанотекстиль) від мікробів, вірусів, різних видів опромінення, пуль, холоду, перегріву тощо. Широке застосування у медицині має лікувальний та медичний нанотекстиль (захисний одяг медперсоналу, натільна та постільна білизна для хворих, лікувальні пов’язки, різноманітні елементи протезів, засоби функціонування серцево-судинної і кровоносної систем тощо).

Міжнародна наукова спільнота все ширше розгортає дослідження щодо використання наноматеріалів. Створена міжнародна робоча група експертів 3 нанотехнологій для розробки нових стандартів для токсикологічних досліджень та ідентифікації ризиків [3-5]. Що стосується України, то при застосуванні чинного законодавства щодо забезпечення зниження ризиків для здоров’я людини, спричинених чинниками довкілля різної природи, закон вимагає проведення аналізу ризику. Аналіз ризику визначається як «процес, що складається із трьох взаємозв'язаних компонентів: оцінка ризику, управління ризиком та повідомлення про ризик» («Закон України про санітарно-епідемічне благополуччя населення»). Таким чином, очевидно, що на сьогодні ми стоїмо перед необхідністю першого етапу аналізу ризиків від застосування нанотехнологій та наноматеріалів - ідентифікації та характеристики небезпеки, оцінки впливу, характеристики ризику. Крім цього, необхідно підвищити рівень обізнаності суспільства про переваги, ризики та оцінку потенційних наслідків від застосування нанотехнологій.

Висновки та перспективи подалыших досліджень. Використання нанотехнологій у текстильному виробництві дозволить підвищити механічні властивості текстилю, покращити стійкість до дії хімікатів, вогню, холоду та спеки, мікроорганізмів, покращити електричні властивості, здатність до оздоблення та фарбування тощо. 
Отже, можна стверджувати, що у ході наукових досліджень ризиків і небезпеки наноматеріалів в текстильній промисловості, необхідно використовувати надійні методи. Будь-які недоліки в науковій оцінці ризику викликатимуть негативне ставлення суспільства до нанотехнологій, що може призвести до сповільнення розвитку нових перспективних технологій.

Проте комерційний розвиток нанотехнологій та їх численні застосування можуть спричинити широкий спектр загроз здоров'ю людини. Наноматеріали, які вже використовуються в текстильній промисловості, потрапили на ринок в умовах недостатнього екогігієнічного нагляду, який має бути побудований з урахуванням їх нетрадиційних властивостей. Враховуючи обмеженість даних щодо впливу наночастинок на організм, необхідно проводити обов'язкові фармакокінетичні та токсикологічні дослідження перед широкомасштабним їх виробництвом та використанням.

\section{Література}

1. Галик I. С. Використання нанотехнологій у формуванні асортименту та якості текстилю / I. С. Галик, Б. Д. Семак // Вісник Хмельницького національного університету. Технічні науки. - 2013. - No4. - С. 108-113.

2. Пахолюк О.В. Особливості використання лляних волокон у виготовленні медичного текстилю / О.В. Пахолюк, О.І. Передрій // Вісник ХНУ. - 2017. - № 1. - $\quad$ С. 56 - 60.

3. Кричевский Г.Е. Нано-, био-, химические технологии и производство нового поколения волокон, текстиля и одежды. Издание первое / Г.Е. Кричевский. - М. : 2011. $528 \mathrm{c}$.

4. Михайленко В. М. Нанотехнології - перспективи застосування та ризики для здоров'я людини / В. М. Михайленко, П. М. Михайленко, Л. О. Єлейко // Онкологія. - Т. 10, № 4. - 2008. - С. 420-427.

5. Полова Ж.М. Використання нанотехнологій у косметичних засобах - великий потенціал чи потенційний ризик? / Ж. М. Полова, I. С. Чекман // Запорожский медицинский журнал. 2013. - №5 (80) 2013. - С. 95-98.

Цель. Обобщение результатов европейских и украинских научных исследований рынка текстильных материалов с использованием нанотехнологий по подтвержденной их безопасности и возможной токсичности и определения потенщиальных рисков.

Методика. При проведении исследований использовали предусмотренные действующими государственными стандартами методы. Выполнили обзор источников товароведческой $u$ медицинской информации, осуществили мониторинг $и$ систематизацию полученных данных.

Результаты. Можно утверждать, что в ходе научных исследований рисков $и$ опасности наноматериалов в текстильной промьшленности, необходимо использовать надежные методы. Любые недостатки в научной оценке риска вызывать негативное отношение общества к нанотехнологиям, что может привести к замедлению развития новых перспективных технологий. Однако коммерческое развитие нанотеинологий и их многочисленные применения могут вызвать широкий спектр угроз здоровью человека. Наноматериаль, которые уже используются в текстильной промышленности, попали на 
рынок в условиях недостаточного екогигиеничного надзора, который должен быть построен с учетом их нетрадииионных свойств. Учитывая ограниченность данных о влиянии наночастиц на организм, необходимо проводить обязательные фармакокинетические и токсикологические исследования перед широкомасштабным их производством и использованием.

Научная новизна. Обобщены результаты европейских и украинских научных исследований рынка текстильных материалов с использованием нанотехнологий по подтвержденной $u x$ безопасности $u$ возможной токсичности $u$ определения потенциальных рисков.

Практическая значимость. Представлень результать исследования дают основания полагать, что наночастищы с размерами и площадью поверхности близкими к частии сверхмалого размера вероятно будут вызывать тяжелье заболевания, а некоторые еще и с длинным латентным периодом. Учитывая широкое индустриальное распространения нанотехнологий, потенциальная угроза загрязнения воздуха и возникновения значительной угрозы для населения.

Ключевые слова: нанотекстиль, нанотехнологии, нановолокна, риски применения нанотехнологий, безопасность использования, потенциальные последствия.

Purpose. Summarizing the results of European and Ukrainian research on the market of textile materials using nanotechnologies as to their confirmed safety and potential toxicity and identification of potential risks.

Methodology. In the course of research, methods provided for by the current state standards were used. They performed a review of the sources of commodity and medical information, monitored and systematized the data received.

Findings. It can be argued that in the course of scientific research on the risks and dangers of nanomaterials in the textile industry, reliable methods need to be used. Any shortcomings in the scientific assessment of risk will lead to a negative attitude of society towards nanotechnologies, which may slow down the development of new promising technologies. However, the commercial development of nanotechnologies and their numerous applications can lead to a wide range of threats to human health. Nanomaterials that are already used in the textile industry have entered the market under conditions of insufficient ecohygienic supervision, which should be built taking into account their non-traditional properties. Given the limited data on the effects of nanoparticles on the body, mandatory pharmacokinetic and toxicological studies are required before their large-scale production and use.

Originality. The results of European and Ukrainian research on the market of textile materials using nanotechnology are summarized in terms of their confirmed safety and possible toxicity and identification of potential risks.

The practical value. The results of the study presented suggest that nanoparticles of size and surface area close to particles of superfluous size are likely to cause serious illnesses, and some with a long latent period. Given the widespread industrial spread of nanotechnology, there is a potential threat of air pollution and a significant threat to the population.

Keywords: nanotext, nanotechnology, nanofibers, risks of nanotechnology application, safety of use, potential consequences.

Рекомендовано до публікації докт.техн.наук. професором Луцьького НТУ Байдаковою Л.І. Дата надходження в редакиію 31.01.2018 